\title{
Characteristics of two complex rock and glacier avalanches and RAMMS simulation of a long-runout disaster in the Sedongpu Basin of the Yarlung Zangbo River downstream in October 2018, Tibet, China
}

\section{Tiantian Zhang}

Chinese Academy of Geological Sciences Institute of Geomechanics

Yueping Yin ( $\nabla$ yinypcgs@hotmail.com )

China Institute of Geo-environment Monitoring

\section{Bin Li}

Chinese Academy of Geological Sciences Institute of Geomechanics

\section{Yang Gao}

Chinese Academy of Geological Sciences Institute of Geomechanics

\section{Meng Wang}

China Geological Survey

\section{Research Article}

Keywords: Tibetan Plateau, Rock and glacier avalanches, Disaster chains, Debris flow, Dynamic process

Posted Date: January 13th, 2022

DOI: https://doi.org/10.21203/rs.3.rs-1238705/v1

License: (c) (1) This work is licensed under a Creative Commons Attribution 4.0 International License. Read Full License 


\section{Abstract}

On October 17 and 29, 2018, two rock and glacier avalanches occurred on the western slope of the Sedongpu Basin upstream of the Yarlung Zangbo River in the Tibetan Plateau, forming the disaster chains and causing damage to many bridges and roads. Based on the comparative analysis of multiple pre-and post-remote sensing images, the initial sliding body, which was composed of rock and glacial material, was located on a steep slope above an elevation of $6000 \mathrm{~m}$. Under the coupling effect of multiple factors such as gravity, rainfall, and weather changes, the initial sliding body detached from the source zone and then transformed into a debris flow after impact and fragmentation. The debris flow traveled downstream and scraped loose glacial till in its path, causing the volume of the sliding body to increase. In addition, the debris flow traveled $10 \mathrm{~km}$ under low frictional resistance, as a result of the lubrication via early rainfall and glacial meltwater. Eventually, the debris flow rushed out onto the valley floor, forming a landslide dam and blocking the Yarlung Zangbo River. The deposit volumes on October 17 and 29 were 20.4 million $\mathrm{m}^{3}$ and 10.1 million $\mathrm{m}^{3}$, respectively, with a total mean thickness of $\sim 22 \mathrm{~m}$. This study provides an insight into the dynamic process as they unfolded, through multitemporal satellite imagery and numerical simulation. Furthermore, we also discuss the potential cause of rock/ice avalanche and disaster scenarios, as well as the tendency of the rock and glacier avalanches are discussed.

\section{Introduction}

In October 2018, two rock and glacier avalanche disaster chains occurred in the Sedongpu Basin, which is located on the left bank of the Yarlung Zangbo River in Tibet, China. A debris flow accumulated at the mouth of the gully to form a giant dam. After the landslide dam breached, the outburst flood caused serious damage in Medog County and to hydropower stations downstream, with over 16000 people affected, and the direct economic loss exceeded 300 million yuan (Chen et al. 2020). On March 22, 2021, a debris flow, the accumulation of which had blocked the Yarlung Zangbo River, occurred again, and the upstream submerged area was $\sim 10 \mathrm{~km}$ in length. Fortunately, the landslide dam breached two days later, and the water level of the dammed lake began to decrease without causing casualties. Geographically, the Sedongpu Basin is located in the plate compressional and collisional zone of the Himalayan region; the basin has the highest elevation on the Earth, the widest terrain elevation difference, and the largest scale. A large number of glaciers and ice lakes are present in high mountainous areas with elevations above $4000 \mathrm{~m}$ asl. Over the past two decades, the Himalayas have experienced a significant increase in temperature, more than the global average, especially in winter (Bhutiyani et al. 2010; Nakamura et al. 2018; Shreshtha et al. 1999). With increasing temperatures due to global warming, glaciers are melting at an increasingly faster rate, and natural hazards in high mountainous areas are associated with glacial activity, such as glacier/rock avalanches, landslides, and debris flows, which have also increased and resulted in the extensive loss of lives and property (Allen et al. 2011; Fischer et al. 2012; Gruber et al. 2017; Kääb et al. 2018; Kirschbaum et al. 2019; Jacquemart et al. 2020). A dammed lake outburst caused by rainfall and melting ice and snow occurred in the Kedarnath district of Uttarakhand, India, leading to 
approximately 6000 people killed and at least 30 hydropower stations damaged in 2013 (Allen et al. 2016; Bhambri et al. 2016). Recently, on February 7, 2021, a rock and glacier avalanches occurred in Chamoli in Uttarakhand, India, which resulted in at least 20 deaths and 177 missing and two hydropower stations under construction in the downstream were destroyed. This hazardous event had a strong international response and attracted the continuous attention of many scholars (Martha et al. 2021; Pandey et al. 2021; Yin et al. 2021; Shugar et al. 2021). However, the mechanism causing rock and glacier disaster chains is extremely complex, with sudden occurrences, fast movements, a wide range of damage and long-runout distances.

Similar high-level glacier/snow geological disasters have frequently occurred; these disasters were affected by seismic activity, rainfall, and climate warming in Tibet, thereby causing serious casualties and infrastructure damage (Shang et al. 2003; Yin and Xing, 2012; Cui and Jia, 2015). For example, a massive landslide occurred in Zamunong Gully of Yigong, Tibet; it was the largest landslide and river blockage event in China in the past 100 years and has attracted widespread attention from many scholars (Yin, 2011; Yin and Xing, 2012; Delaney and Evans, 2015; Wu et al. 2020). The source area was located on a slope with an elevation of $\sim 5000 \mathrm{~m}$ asl with deposits of approximately $280 \sim 300$ million $\mathrm{m}^{3}$ that accumulated at the mouth of the gully, blocked the Yigong Zangbo River, and produced a dammed lake. Eventually, the outburst flood occurred with a maximum peak flow of $\sim 130000 \mathrm{~m}^{3} / \mathrm{s}$ after the dam burst, causing serious damage to downstream roads and bridges. In 2018, two large rock landslides occurred, and both blocked the Jinsha River, thereby forming a barrier lake in Baige village in Jiangda County, Tibet. The upstream villages and towns were submerged due to the barrier lake. The flooding reached the Sichuan and Yunnan regions and caused some damage after the dam breaking (Zhong et al. 2020; Tian et al. 2020; Zhang et al. 2020). Generally, high-level geological disasters have large potential energy. Therefore, the sliding body travels at a high speed and disintegrates quickly after the conversion of gravitational potential to kinetic energy during which a large amount of deposit material in the path is scoured, resulting in an increase in the volume of the initial landslide mass. The sliding bodies travel suddenly a long-runout distance as a result of lubrication by snow and glacial meltwater. As a result, these problems originating from high-level hazards, including mechanisms, formation patterns, early identification, monitoring and early warning, have gradually become research focuses (Xu et al. 2011; Yin et al. 2016). Historically, the Sedongpu Basin has experienced many high-level disaster events that have blocked the Yarlung Zangbo River. Therefore, it is necessary to study the dynamic mechanism of the highlevel disaster chain that occurred in the Sedongpu Basin to provide a better scientific basis for risk prediction. In this study, based on the two rock and glacier avalanches that occurred on October 17 and 29,2018 , we conduct a detailed analysis of disaster characteristics combined with multitemporal remote sensing images. In addition, RAMMS is used to simulate the dynamic process, and we also discuss the disaster causes, evolution mechanisms and trends of disaster chains in the future.

\section{Characteristics Of The Sedongpu Basin Rock And Glacier Avalanches On October 17 And 29, 2018}


Located on the western slope of the Gyala Barwa Mountain (elevation: $7294 \mathrm{~m}$ asl), the rock and glacier avalanches (located at: $29^{\circ} 45^{\prime} 1.47^{\prime \prime} \mathrm{N}$ and $94^{\circ} 56^{\prime} 14.37^{\prime \prime} \mathrm{E}$ ) originated on a steep slope of the Sedongpu Basin, which is part of the canyon zone on the left bank of the Yarlung Zangbo River (Fig. 1). Moreover, the Sedongpu Basin has been an also areas with frequent massive chain disasters on the Tibetan Plateau. Topographically, this region is exceedingly rugged with steep slopes, with different elevations ranging from $2700 \mathrm{~m}$ asl to $7500 \mathrm{~m}$ asl. The landforms include high mountains, narrow valleys, and deep gorges. The highest peak in the region is Namcha Barwa Mountain, with an elevation of $7782 \mathrm{~m}$ asl. The Sedongpu Basin occupies approximately $66.8 \mathrm{~km}^{2}$ with abundant glaciers and snow in the upstream valley which occupy an area of $\sim 23.6 \mathrm{~km}^{2}$.

Geologically, the study area is located on the Greater Himalaya tectonic unit, which also coincidentally happens to be location of the strong collisional belt between the Indian and Eurasian plates. In addition, this region has many active faults and frequent earthquakes due to the strong compression and collision between plates. Therefore, these young mountains are structurally fragile and are exposed to extreme climates that are common in the area. The main strata in the region are composited of the Proterozoic Namcha Barwa Group and Quaternary loose sediment (Fig. 2). The lithologies include plagioclase gneiss, granulite, monzonite gneiss, etc. The frequency of high-level geological disasters blocking the river in the Sedongpu Basin has increased since 2015. Seven disaster events from 2015 to 2021 occurred in the Sedongpu Basin at different scales (Table 1). Among them, two disaster events occurred in October 2018, and both blocked the Yarlung Zangbo River with an upstream submerged area length of $20 \mathrm{~km}$. After the dam burst, the outburst flood caused serious damage to the downstream towns and infrastructure. Nowadays, a large number of deposits are accumulated in the Yarlung Zangbo River, forming a narrow river channel. Recently, two small debris flows blocked the river in 2021 with a submerged area length of $15 \mathrm{~km}$, but did not produce danger to the upstream and downstream villages. 
Table 1

High-level geological disaster events from 2015 to 2021 in the Sedongpu Basin

\begin{tabular}{|c|c|c|c|c|c|}
\hline No & Date & Type of failure & $\begin{array}{l}\text { Total deposits volume } \\
\left(\mathrm{m}^{3}\right)\end{array}$ & Scale & $\begin{array}{l}\text { Dammed } \\
\text { river! }\end{array}$ \\
\hline 1 & $\begin{array}{l}2017-10- \\
22\end{array}$ & Debris flow & $3 \times 10^{6}$ & Large & Yes \\
\hline 2 & $\begin{array}{l}2017-12- \\
21\end{array}$ & $\begin{array}{l}\text { Rock and glacier } \\
\text { avalanches }\end{array}$ & $1.1 \times 10^{7}$ & Oversized & Yes \\
\hline 3 & $\begin{array}{l}2018-10- \\
17\end{array}$ & $\begin{array}{l}\text { Rock and glacier } \\
\text { avalanches }\end{array}$ & $2.05 \times 10^{7}$ & Oversized & Yes \\
\hline 4 & $\begin{array}{l}2018-10- \\
29\end{array}$ & $\begin{array}{l}\text { Rock and glacier } \\
\text { avalanches }\end{array}$ & $1 \times 10^{7}$ & Oversized & Yes \\
\hline 5 & 2019 & Debris flow & $\otimes 1 \times 10^{5}$ & Small & No \\
\hline 6 & $\begin{array}{l}2021-3- \\
22\end{array}$ & Debris flow & $\otimes 1 \times 10^{5}$ & Small & Yes \\
\hline 7 & $\begin{array}{l}2021-8- \\
10\end{array}$ & Debris flow & $\otimes 1 \times 10^{5}$ & Small & Yes \\
\hline
\end{tabular}

Note: small, $1 \sim 10 \times 10^{4} \mathrm{~m}^{3}$; large, $100 \sim 1000 \times 10^{4} \mathrm{~m}^{3}$, oversized, more than $1000 \times 10^{4} \mathrm{~m}^{3}$.

\section{Long-runout Avalanche Debris-flood Disaster Chain}

The rock and glacier mass detached from a high position at an elevation of $\sim 6500 \mathrm{~m}$ asl. During the course of sliding, the initial mass rapidly transformed into a debris flow that mixed with snowmelt and glacial meltwater as a result of impact and friction between the debris flow and valley floor.

Simultaneously, the debris flow scraped the loose deposits, such as colluvial deposits, glacial till, snow, and glacial material. Finally, the debris flow accumulated downstream, blocking the river and forming a large dammed lake in the upstream landslide dam. This hazard chain mode is summarized as follows: complex rock and glacier avalanches $\rightarrow$ debris flow $\rightarrow$ river blocking $\rightarrow$ dammed lake $\rightarrow$ outburst flood. The disaster chain process consisted of four sections, including the source zone, dynamic erosion zone, debris flow accumulation and damming zone, and flood flow zone.

\section{Source zone}

The source zones in which the two hazards occurred were located on the mountain to the left of the upstream Sedongpu Basin in October 2018, with an elevation of $\sim 6000 \mathrm{~m}$ asl (Fig. 3). The source area of the disaster that occurred on October 17, 2018, was $\sim 336000 \mathrm{~m}^{3}$. Based on the pre- and post-satellite images (Fig. 4), glacier cracks appeared along the front and middle margins of the sliding mass in 2014, with lengths of $\sim 150 \mathrm{~m}$ and widths $20 \mathrm{~m} \sim 30 \mathrm{~m}$. Subsequently, the tension cracks continually extended and widened between 2015 and 2017, the quantity increased to $\sim 12$, and the longest crack reached $\sim 210$ 
m. Fig. 4d and Fig. 4e show that some glacial till under the source area slid and formed a glacial lake. According to records, a debris flow indeed occurred between February and December 2017, arising mainly from melting glaciers (Table 1). Eventually, the landslide mass detached from the source area and directly scoured the residual glacial till below. The other source area of disaster that occurred on October 29 was located on a steep slope and occupied an area of $\sim 0.29 \mathrm{~km}^{2}$. It was obvious from the remote sensing images between 2014 and 2017 that glacier cracks gradually appeared and widened. In addition, signs of melting glaciers were recognized in the source area after the landslide mass slipped, in which the residual material mixed with the water and became a viscous feature (Fig. 5).

\section{Dynamic erosion zone}

The dynamic erosion zone was located at elevations ranging from $3000 \mathrm{~m}$ asl to $3800 \mathrm{~m}$ asl, with $~ 5 \mathrm{~km}$ along the valley floor (Fig. 3). The upstream section, which was mainly composed of colluvial deposits more than $30 \mathrm{~m}$ thick, had a gentle and spacious terrain that contributed to material accumulation. The downstream valley was long and narrow, where the bedrock outcrop was clearly visible, showing a " $\mathrm{V}$ "shaped feature in cross section. Due to scouring by rainstorms or debris flows, small rockfalls or landslides have frequently occurred on both sides of the slopes, during which abundant colluvial materials accumulated on the valley floor, thereby providing a material basis for the next scraping of debris flows or debris avalanches and causing magnification of disaster scale.

\section{Debris flow accumulation and damming zone}

The debris flow accumulation and damming zone is approximately $1800 \mathrm{~m}$ long, ranges in elevation from $2700 \mathrm{~m}$ asl to $3000 \mathrm{~m}$ asl and has a gradient ratio of $166 \%$ (Fig. 3). Based on the analysis of remote sensing images and ground photographs (Fig. 7), the deposit area was composed of area $\nabla$ and area $\Downarrow$. Among them, area $₫$ was estimated to have a volume of $\sim 2.400 \times 10^{7} \mathrm{~m}^{3}$, which formed on 17 October with a thickness of $20 \mathrm{~m} 40 \mathrm{~m}$; this deposit directly blocked the river and resulted in a dammed lake forming upstream. Area $₫$ was located at the river channel where the deposit volume was $\sim 1.76 \times 10^{7} \mathrm{~m}^{3}$ with a length of $\sim 6 \mathrm{~km}$ due to a " 10.29 " disaster event. These sediment deposits in the river were mainly composed of soil, rock, and glaciers. Therefore, the landslide dam was unstable and easily failed. Fig. 8 shows two geophysical profiles whose positions are shown in Fig. 7a. It was speculated that the scopes ranging from $10 \mathrm{~m}$ to $30 \mathrm{~m}$ were sediment deposits, with a low resistivity of less than $400 \Omega \bullet \mathrm{m}$. Apparently, the riverbed was uplifted after damming.

In addition, due to the accumulation of a large amount of sediment deposits in the river after disaster events in October 2018, the riverbed was raised and the river channel whose width ranged from $20 \mathrm{~m}$ to $40 \mathrm{~m}$ was narrowed. Therefore, a small debris flow would have also blocked the river. In 2021, two small scale high-level glacial rock avalanches occurred in the Sedongpu Basin, both of which caused a temporal river blocking event. The first occurred on March 22, in which river blocking lasted for $\sim 3$ days (Fig. 9a). The upstream submerged lake area was approximately $10 \mathrm{~km}$ long, with the water level rising by $1 \mathrm{~m}$. However, due to the small volume $\left(<100000 \mathrm{~m}^{3}\right)$, as the lake water level exceeded the dam crest, 
the right side of the dam breached and resulted in further flooding. Nevertheless, the flood was too small in scale to be destructive without inducing casualties downstream. On August 10, glacier avalanches occurred again in the Sedongpu Basin, which quickly transformed into debris flows and directly blocked the Yarlung Zangbo River. This hazard may have been caused by rising temperatures, which accelerated the rate of glacial melting. According to aerial photos (Fig. 9b, 9c), the submerged lake area was $\sim 8 \mathrm{~km}$ long, with the water level rising by $1 \sim 2 \mathrm{~m}$, which directly submerged the bridge in Gyala village and low terrain in the river.

\section{Flood flow zone}

The flood flow zone was located downstream of the landslide dam in the Yarlung Zangbo River, with a length of $\sim 100 \mathrm{~km}$ and an elevation difference of $\sim 1500 \mathrm{~m}$. Many towns were distributed along the Yarlung Zangbo River in this area. Among the previous disaster events, two large floods, which both occurred in October 2018, caused the most serious damage due to the landslide dam bursting. First, a barrier lake quickly formed upstream of the barrier dam after a debris flow blocked the Yarlung Zangbo River on October 17. At 12:00 noon on October 17, the upstream submerged lake area was $\sim 27 \mathrm{~km}$ long, the lake water level rose approximately $40 \mathrm{~m}$ above the original level and was still rising at a mean rate of $0.61 \mathrm{~m}$ per hour, with a storage capacity of approximately 150 million $\mathrm{m}^{3}$. Correspondingly, the water level decreased from $74.82 \mathrm{~m}$ to $73 \mathrm{~m}$, and the flow rate also decreased from $3430 \mathrm{~m}^{3} / \mathrm{s}$ to $2620 \mathrm{~m}^{3} / \mathrm{s}$ in the downstream Dexing Town Hydrological Station after landslide dam formation. The outburst flood occurred at around 13:30 pm on October 19, with a peak breaching flow of $\sim 32,000 \mathrm{~m}^{3} / \mathrm{s}$, resulting in 16,600 affected people, 7100 urgently resettled people, and a large amount of damage to infrastructure, such as roads, canals, and water supply pipelines. Second, the maximum water depth of the barrier lake was $\sim 77 \mathrm{~m}$, which occurred on 29 October, and the water storage capacity reached $3.2 \times 10^{8} \mathrm{~m}^{3}$. At 9:30 on October 31, a natural overflow occurred on the right side of the barrier dam, and the maximum flow rate reached $1.8 \times 10^{4} \mathrm{~m}^{3} / \mathrm{s}$ at 12:30. Subsequently, the downstream Dexing Town Hydrological Station had the largest peak discharge of $\sim 1.25 \times 10^{4} \mathrm{~m}^{3} / \mathrm{s}$ at $18: 30$ until the flood danger was relieved at 9 am on November 1.

\section{Disaster Chain Simulation By Ramms 4.1 Introduction to RAMMS}

Rapid mass movements simulation (RAMMS) is a professional dynamic numerical simulation analysis software for debris avalanches designed by the Swiss Institute of Ice, Snow and Avalanche (SLF). Based on a two-dimensional numerical calculation model, RAMMS can quickly simulate debris avalanches, rockfalls, and debris flows, and obtain motion parameters including motion distance, velocity impact pressure, and flow path, in three-dimensional terrain (Christen et al. 2010). In recent years, Rapid Mass Movement Simulation (RAMMS) has been widely used to analyze the dynamic process of geological disasters such as mudslides, avalanches, and rock slides in high mountains. Singh et al (2020) used 
RAMMS to simulate the Chowkibal-Tangdhar (CT) -8 avalanche movement in India in 2018. The results showed that the maximum avalanche speed was $25 \mathrm{~m} \cdot \mathrm{s}^{-1}$, and the accuracy of this calculation was verified based on ground observation data. Based on regional geological surveys, Gan and Zhang (2019) used RAMMS to predict the debris flow in Luzhuang Gully, China, and indicated that the Voellmy model is more suitable for simulating the movement process of debris flows. According to the different motion characteristics of landslide masses, RAMMS sets up three modules: avalanche, debris flow debris flow and rockfall. In this paper, the RAMMS: DEBRIS FLOW module is used for numerical calculation, and the calculation steps are shown in Fig. 11.

\subsection{Model}

In the continuum model, the debris avalanche is assumed to be an unstable and heterogeneous fluid. Based on the continuum model and fluid mechanics theory, RAMMS uses the Voellmy friction law to accurately simulate the movement of debris avalanches under complex three-dimensional terrain conditions. Moreover, the model also considers the solid phase and the viscous or turbulent fluid phase resistance, which is suitable for the simulation of debris avalanches in valley floors. The model further divides the friction resistance into two parts: dry Coulomb friction (coefficient $\mu$ ) and viscous-turbulent friction (coefficient $\varepsilon$ ), (Voellmy, 1955; Salm et al. 1990). The friction coefficients are responsible for the behavior of the flow. $\mu$ dominates when the flow begins to stop, and $\varepsilon$ dominates when the flow is running quickly. In version 1.6.20, the model also introduces yield stress, which is more suitable for ideal plastic materials. Its formula is as follows:

$\mathrm{S}=\mu N+\frac{\rho g u^{2}}{\epsilon}+\square 1-\mu \square N_{0}-(1-\mu) N_{0} e^{-\frac{N}{N_{0}}}$

where: $S$ is the friction resistance $(\mathrm{Pa}), \rho$ is the density $\left(\mathrm{kg} / \mathrm{m}^{3}\right), \mathrm{g}$ is the gravitational acceleration, $\mu$ is the friction coefficient, $u$ is the flow velocity (m.s-1), $\varepsilon$ is the viscous- turbulent friction coefficient, $N$ is the normal stress $(\mathrm{Pa})$, and $\mathrm{N}_{0}$ is the yield stress $(\mathrm{Pa})$.

In addition, according to the actual movement, RAMMS sets up an erosion module with the critical shear stress. When the shear stress generated by debris avalanches exceeds the critical shear stress, it can erode sediments in the channel. The erosion parameters are obtained by many back calculations corresponding to the actual situation.

\subsection{Recommended parameters}

To successfully start a new RAMMS project, a few important preparations are necessary. First, a digital elevation model (DEM) generally can be used to build terrain models in RAMMS. However, a high resolution DEM produces more accurate simulation results than a low resolution DEM. Second, the release and erosion areas can be directly delineated in RAMMS according to the results of field investigations or satellite image interpretation. We also assign other values, such as the thickness, erosion rate, and maximum erosion depth. The friction coefficients ( $\mu$ and $\varepsilon$ ) are the essential parameters 
that directly control the movement distance and reflect accumulation characteristics. We obtain the appropriate friction parameter values by many back calculations, and the concrete parameter values are shown in Table 2.

Table 2

RAMMS model parameter values for the Sedongpu Basin disaster chain of October 17, 2018

\begin{tabular}{|c|c|c|}
\hline Digital terrain model & Simulation grid resolution (DEM) & $12.5 \mathrm{~m}$ \\
\hline \multirow[t]{3}{*}{ Release area } & Area & $0.33 \mathrm{~km}^{2}$ \\
\hline & Block depth & $30 \mathrm{~m}$ \\
\hline & Block density & $2500 \mathrm{~kg} / \mathrm{m}^{3}$ \\
\hline \multirow[t]{3}{*}{ Erosion area } & Erosion material density & $2000 \mathrm{~kg} / \mathrm{m}^{3}$ \\
\hline & Erosion rate & $0.025 \mathrm{~m} / \mathrm{s}$ \\
\hline & Max erosion depth & $25 \mathrm{~m}$ \\
\hline \multirow[t]{4}{*}{ Friction parameters } & & \multirow[t]{2}{*}{0.12} \\
\hline & friction coefficient $(\mu)$ & \\
\hline & & \multirow[t]{2}{*}{$1200 \mathrm{~m} / \mathrm{s}^{2}$} \\
\hline & Viscous coefficient $(\epsilon)$ & \\
\hline
\end{tabular}

\subsubsection{Debris flow velocity}

Figure 12 shows the simulation result of the debris flow velocity, and the total simulation time was $545 \mathrm{~s}$. At $\mathrm{t}=50 \mathrm{~s}$, the rock and glacier mass fell onto the gentle slope below, and the maximum velocity reached $34 \mathrm{~m} \cdot \mathrm{s}^{-1}$. At $\mathrm{t}=100 \mathrm{~s}$, the sliding body that impacted and entered the valley floor was transformed into fragmented clasts, with a maximum velocity of $\sim 33 \mathrm{~m} \cdot \mathrm{s}^{-1}$. The traveling direction changed by approximately $90^{\circ}$ due to blocking by the opposite mountain. At $t=200 \mathrm{~s}$, the debris flow reached the middle of the valley floor with a maximum velocity of $\sim 38 \mathrm{~m} \cdot \mathrm{s}^{-1}$ and a movement distance of $\sim 4 \mathrm{~km}$. At $\mathrm{t}=300 \mathrm{~s}$, the debris flow traveled to the Yarlung Zangbo River with a mean velocity of $\sim 30 \mathrm{~m} \cdot \mathrm{s}^{-1}$. After $\mathrm{t}=$ $400 \mathrm{~s}$, the debris flow accumulated on the downstream path and blocked the Yarlung Zangbo River. Then the upper debris flow slowed down, as a result of blocking the front edge deposits. In terms of velocity change, the debris flow experienced four stages: acceleration $\rightarrow$ collision deceleration $\rightarrow$ long-runout even pace $\rightarrow$ accumulation deceleration.

\subsubsection{Debris flow sediment depth}


Figure 13 shows the simulation results of the debris flow sediment depth, from which the rock and glacier mass, sliding down the slope, impacted the valley floor below and the opposite mountain after $\mathrm{t}=50 \mathrm{~s}$. Then, the motion direction changed from southwest to southeast, and the maximum accumulation thickness was $35 \mathrm{~m}$. At $\mathrm{t}=100 \mathrm{~s}$, the debris flow continuously scraped the glacial till, which was located on the gentle slope below, along with old colluvium along the path, with a movement distance of $\sim 2 \mathrm{~km}$ and a maximum accumulation thickness of $\sim 38 \mathrm{~m}$. At $t=300 \mathrm{~s}$, the front margins of the debris flow, reaching the Yarlung Zangbo River, began to accumulate. After $\mathrm{t}=400 \mathrm{~s}$, debris flows accumulated on the river and blocked the river, further forming a dammed lake upstream. Eventually, the total volume of the debris flow reached $\sim 22$ million $\mathrm{m}^{3}$, and the average depth was $18 \mathrm{~m}$, which was approximately 3 times the original volume of the failed mass.

\section{Discussions}

\subsection{Causes of rock and glacier avalanches}

The distribution pattern, mechanism, and mode of geological disasters on the Tibetan Plateau are obviously different. The Tibetan Plateau has become the area with the most widespread and severe highlevel and long-runout geological disasters in China and worldwide, with an extremely complex geological structure, steep topographical height difference, strong seismic activity, and variable hydrometeorology. Therefore, the causes of hazards that frequently occur in the Sedongpu Basin mainly involve three aspects: earthquakes, weather changes, and rainfall.

\section{(1) Earthquakes}

Earthquakes play an important role in the deformation and failure of rock masses. Frequent and intensive seismic activities generally lead to rocks loosening, during which many cracks are formed inside the rocks. These cracks provide a good channel for rainfall and snowmelt infiltration, which leads to further widening of cracks and accelerate slope failure. Simultaneously, earthquakes usually generate seismic forces that can trigger landslides or rockfalls. When the seismic force is sufficiently large, it causes large or oversized landslides, which are more destructive than ordinary disasters. According to records of earthquake events that occurred in the study area and adjacent areas, the quantity of events with magnitudes in the rangs of $4 \leq \mathrm{Ms}<5$ is approximately 264 , the number of earthquakes with magnitudes of $5 \leq M s<6$ is $\sim 264$, and the number of Ms $₫ 6$ earthquakes that have been recorded are more than 20 . An earthquake of Ms= 8.6 that occurred in Chayu town in Medog County in 1950 was the largest earthquake in the region. In this earthquake, abundant landslides were triggered, and two snow peaks produced large-scale avalanches, with damage to many houses. However, the spatial distribution of earthquakes is a cluster, which is mainly located at the large bend of the Yarlung Zangbo River where fragmenting mountains and high-level geological disasters occur (Fig. 14). According to the fifthgeneration peak seismic acceleration in China (GB18306-2015), the peak seismic acceleration in the study area reaches $0.3 \mathrm{~g}$, while the peak seismic acceleration in the surrounding areas is more than $0.1 \mathrm{~g}$. The peak ground motion acceleration in the Medog region, which approaches the Sedongpu Basin, reaches $0.4 \mathrm{~g}$. Based on the ground survey, a large amount of loose material is visible in the Sedongpu 
Basin, mainly resulting from chronic seismic activity. The internal structural planes controlling the sliding mass gradually shift and extend because earthquakes, with the shear strength decreasing chronically. Eventually, under the coupling of internal and external factors, a massive rock mass would failed, and a secondary disaster chain was also induced.

\section{(2) Weather changing}

Figure 15 shows a temperature variation curve from October 1 to 30,2018 . The red and blue lines represent the maximum and minimum temperatures, respectively, whereas the black lines show the temperature difference. In the " 10.17 " disaster event, the temperature difference was $10{ }^{\circ} \mathrm{C}$, with a maximum temperature of $15{ }^{\circ} \mathrm{C}$ and a minimum temperature of $5{ }^{\circ} \mathrm{C}$. However, the temperature difference at the slope on the top of the mountain changed more, which caused fissure water to frequently transform between solid and liquid states, thereby accelerating rock mass failure. The temperature difference changed greatly after October 22, with a linear growth trend. Moreover, the temperature difference on October 29 reached approximately $19{ }^{\circ} \mathrm{C}$, with a maximum temperature of 16 ${ }^{\circ} \mathrm{C}$ and a minimum temperature of $-2.4{ }^{\circ} \mathrm{C}$. As the temperature rose, the glacier and snow melted rapidly. The friction resistance between the loose deposits and the ground decreased, as a result of mixing some of meltwater. As the temperature rapidly decreased, the fissure water in the rock mass rapidly feezed and led to volume expansion. As a result, this process produced a frost heaving force, which expedited the expansion of cracks until the failure of the rock mass. Based on the above analysis, the temperature changes, especially the greater temperature difference between day and night, accelerated the weathering and freeze/thaw effect of the rock mass.

\section{(3) Rainfall}

Figure 16 shows the monthly mean rainfall and temperature in Milin County in 2018 . The rainy season mainly occurred from June to September, and the monthly average rainfall was more than $60 \mathrm{~mm}$. In addition, the monthly mean temperature in the three months was $15^{\circ} \mathrm{C} \sim 16^{\circ} \mathrm{C}$, the glacier melted rapidly, and some glacial meltwater penetrated along rock cracks. The rainfall in September 2018 exceeded the multiyear mean rainfall (Fig. 17). Subsequently, abundant rainwater easily penetrated along the cracks of the sliding body, producing dynamic and hydrostatic pressures that facilitated the expansion of cracks. The shear strength of the sliding surface gradually decreased due to lubrication and seepage pressure of pore water, resulting in creep displacement increasing in the sliding body. Massive ice or snow existed in glacial till and began to melt under high temperature conditions. The glacial till gradually changed from an unsaturated state to a saturated state and was easily scraped under the impact of debris flows as a result of rainfall and glacial meltwater. Finally, the initial sliding mass detached from the source area due to mixing a large amount of water and transformed into a debris flow, which scraped loose deposits on the movement path and caused disaster magnification.

\subsection{Analysis of disaster scenarios}

The deformation and failure evolution of the hazard chain is shown in Fig. 18. Due to the steep slopes on both sides of the valley and frequent seismicity, abundant colluvial slope deposits and moraines

Page $11 / 22$ 
accumulated in the valley floor, which provided an abundant material basis for the volume increase in the subsequent debris flow (Fig. 18a). Moreover, as creep displacement increased, with long-term seasonal and cyclic day/night freezing and thawing, the fissure water in the rock mass continuously changed from the solid to the liquid state, and further produced a frost heaving force, which accelerated the deterioration of the rock mass and formed a potential sliding surface. At the same time, the rock mass cracks widened and connected as a result of the hydrostatic pressure and hydrodynamic pressure produced by rainfall and glacial meltwater. In particular, the rock deterioration of the mountain peaks was much more serious than that at the foot of the mountains due to the seismic amplification effect. On October 17 and 19, 2018, the glacier rapidly melted owing to the abrupt rise in temperature. Therefore, some of glacier meltwater mixed with loose deposits after entering the valley, resulting in a decrease in shear strength between the deposits and ground. When the potential sliding surface was connected, the rock and glacier mass rapidly detached from the source area. During the disintegration process (Fig. 18b, 18c), the sliding body that resulted from fragmentation and impact was quickly transformed into a debris flow. A large amount of heat, which was derived from friction and collision, melted the glacier and snow inside the rock mass. Simultaneously, under the lubrication of meltwater, the friction resistance between the sliding body and the ground decreased, resulting in movement along a long-runout distance. However, the loose deposits that mixed with abundant meltwater were saturated or partly saturated along the travel path. Then, under the impact of the debris flow, they were easily scraped and trapped, resulting in the increase in the debris flow volume. Finally, the debris flow that blocked the river and formed a dammed lake traveled to the Yarlung Zangbo River (Fig. 18d). When the dam burst, the flood disaster formed downstream.

\subsection{Tendency of the rock and glacier avalanches}

The Himalayas are one of the largest glacierized areas outside the polar regions, with a total glacier coverage of $22800 \mathrm{~km}^{2}$ (Bolch et al. 2012). Climate change poses a serious challenge to snow and glacier coverage. With an increase in temperature in high mountainous regions, glacier and snow-covered areas will diminish due to increased melting of snow and glacier as well as reduced accumulation of snow (Khadka et al. 2014). Simultaneously, a series of problems, such as glacier shrinkage and snow line rise, have begun to appear and have cause many disaster problems (Fujita et al. 2006; Rafiq and Mishra, 2016; Singh and Jain, 2002; Tawde et al. 2017). The rate of glacier retreat is believed to be approximately 10 15 $\mathrm{m} \mathrm{year}^{-1}$ and is an increasing (Winiger et al. 2005). The glacier shrinkage rates in Himalayas are regionally variable: $\sim 0.2$ to $~ 0.7 \%$ year $^{-1}$ from 1960 to 2001-2004 in the Indian Himalayas (Kulkarni et al. 2011), $0.12 \pm 0.07 \%$ year $^{-1}$ from 1968 to 2007 in the Garhwal Himalayas (Bhambri et al.2011), and $\sim 0.3$ to $\sim 0.6 \%$ year $^{-1}$ from $\sim 1970$ to $\sim 2005$ in Tibet, China (Nie et al. 2010). An air temperature increase of 2 ${ }^{\circ} \mathrm{C}$ reduced the annual snow water equivalent to $1-7 \%$ (Singh and Kumar, 1997). The Tibetan Plateau, also known as the roof of the world due to its base height residing in the free troposphere, receives large amounts of solar heat flux (Prasad et al. 2009). However, most of the Tibetan glaciers have shown signs of accelerated retreat in recent decades under the trend of global warming (Yao et al. 2007). 
According to meteorological stations in Milin County (Fig. 19), the annual mean temperature is $8.9^{\circ} \mathrm{C}$. However, clearly, the temperature change curve from 1980 to 2019 shows that the temperature has risen by approximately $1.8^{\circ} \mathrm{C}$. Due to rising temperature, glaciers and snow will melt and further accelerate rock weathering. Simultaneously, after mixing with accumulation materials in the gully, the meltwater would easily trigger debris flows or debris avalanches. The annual average rainfall in Milin County from March to October, which accounts for approximately $95 \%$, is $731.2 \mathrm{~mm}$. However, the rainfall from November to February of the next year is relatively small, accounting for approximately $5 \%$ of the yearly rainfall. Abundant rainfall accelerates the deformation and failure of slopes. Therefore, rock and glacier avalanches frequently occur in the Sedongpu Basin, with river-blocking disaster chains. It is also recommended that automatic water level and temperature monitoring stations be established in the Sedongpu Basin for emergency monitoring and early warning work. From the perspective of long-term monitoring, high-resolution satellites are available to recognize chronic deformation.

\section{Conclusion}

Based on the analysis of rock and glacier avalanches that occurred in Sedongpu Basin on 17 and 29 October 2018, we find significant amplification in long-runout disaster chain effects. A disaster-affected body undergoing a rock and glacier avalanche travels, resulting in continuous damage in a short period of time and transforming into debris flow or debris avalanche. Therefore, the ultimate damage far exceeds the initial damage from the avalanche due to the amplification effect. Simultaneously, the disaster chain is composed of avalanches, debris flows, landslide dams, and outburst floods. The most prominent feature resulting from disaster amplification is that the disaster travels far. A debris flow entered the Yarlung Zangbo River and formed a large dam. The dam that formed by abundant glacier and meltwater was so unstable that it burst in a short time. However, the landslide dam volume was too large to wash away by floods, which led to riverbed uplift and river channel narrowing. As a result, the two small-scale debris flows that occurred in 2021 easily caused river blockage. Under the background of global warming, similar rock and glacier avalanches will become more frequent in Sedongpu Basin, small-scale debris flows blocked the river and flooding increased. Consequently, it is imperative that a comprehensive assessment of risk be built. High-resolution remote sensing satellites play an important role in recognizing and monitoring signs of deformation and failure in potential source areas.

Subsequently, we can analyze the disaster evolution tendency by multiperiod satellite images to achieve early monitoring and warning. According to these analyses of satellite images, the relevant departments also can set out scientific policies of disaster prevention and mitigation.

\section{Declarations}

\section{Conflicts of interests}

We declare that we have no financial and personal relationships with other people or organizations that can inappropriately influence our work, there is no professional or other personal interest of any nature or kind in any product, service and/or company that could be construed as influencing the position 
presented in, or the review of, the manuscript entitled, "Characteristics of two complex rock and glacier avalanches and RAMMS simulation of a long-runout disaster in the Sedongpu Basin of the Yarlung Zangbo River downstream in October 2018, Tibet, China".

\section{Acknowledgements}

We acknowledge support from the Geological Survey Project of CGS (Grant No.DD20211540, DD20190637, DD20221748), National Natural Science Foundation of China (Grant No.41907257 and 42177172), and the National Key Research and Development Program of China "The Disaster Pattern and Risk Prevention Technology of Large Landslides in the Karst Mountain Area" (Grant No.2018YFC1504800).

\section{References}

Allen SK, Cox SC, Owens IF (2011) Rock avalanches and other landslides in the central Southern Alps of New Zealand: a regional study considering possible climate change impacts. Landslides 8: 33-48. https://doi.org/10.1007/s10346-010-0222-z

Allen SK, Rastner IP, Arora IM, Huggel IC, Stoffel IM (2016) Lake outburst and debris flow disaster at Kedarnath, June 2013: hydrometeorological triggering and topographic predisposition. Landslides 13: 1479-1491. https://doi.org/10.1007-/s10346-015-0584-3

Bhambri R, Bolch T, Chaujar R, Kulshreshtha S (2011). Glacier changes in the Garhwal Himalaya, India, from 1968 to 2006 based on remote sensing. Journal of Glaciology 57(203), 543-556. https://doi.org/10.3189/002214311796905604

Bhambri R., Mehta M, Dobhal DP, Gupta AK, Pratap B, Kesarwani K, Verma A, (2016) Devastation in the Kedarnath (Mandakini) Valley, Garhwal Himalaya, during 16- 17 June 2013: a remote sensing and ground-based assessment. Nat Hazards 80(3): 1801-1822. https://doi.org/10.1007/s11069-015-2033-y

Bhutiyani MR, Kale VS, Pawar NJ (2010) Climate change and the precipitation variations in the northwestern Himalaya:1866-2006. International Journal of Climatology 30(4): 535-

548. https://doi.org/10.1002/joc. 1920

Bolch T, Kulkarni, A V, K A, Huggel C, Stoffel M (2012) The State and Fate of Himalayan Glaciers. Science 336 (6079): 310-314. https://doi.org/10.1126/science. 1215828

Chen C, Zhang LM, Xiao T, He J (2020) Barrier lake bursting and flood routing in the Yarlung Tsangpo Grand Canyon in October 2018. Journal of Hydrology 583:124603. https://doi.org/10.1016/j.jhydrol.2020.124603 
Christen M, Kowalski J, Bartelt P (2010) RAMMS: Numerical simulation of dense snow avalanches in three-dimensional terrain. Cold Regions Science and Technology 63 (1-2): 1-

14. https://doi.org/10.1016/j.coldregions.2010.04.005

Cui, P., Jia, Y., 2015. Mountain hazards in the Tibetan Plateau: research status and prospects. National Science Review 2(4): 397-399. https://doi.org/10.1093/nsr/ nwv061

Delaney KB, Evans SG (2015) The 2000 Yigong landslide (Tibetan Plateau), rockslide-dammed lake and outburst flood: Review, remote sensing analysis, and process modelling. Geomorphology 246: 377393. https://doi.org/10.1016/j.geomorph. 2015.06 .020

Fischer L, Purves RS, Huggel C, Noetzli J, Haeberli, W (2012) On the influence of topographic, geological and cryospheric factors on rock avalanches and rockfalls in high-mountain areas. Natural Hazards Earth System Science 12 (1): 241-254. https://doi.org/10.5194/nhess-12-241-2012

Fujita K, Thompson LG, Ageta Y, Yasunari T, Kajikawa Y, Sakai A, Takeuchi N (2006) Thirty-year history of glacier melting in the Nepal Himalayas. Journal of Geophysical Research Atmospheres 111 (3): 16. https://doi.org/10.1029/2005J D00-5894

Gan JJ, Zhang YX (2019) Numerical Simulation of Debris Flow Runout Using RAMMS: A Case Study of Luzhuang Gully in China. Computer Modeling in Engineering \& Sciences 121 (3): 9811009. https://doi.org/10.32604/cmes. 2019.07337

Gruber S, Fleiner R, Guegan E, Panday P, Schmid MO, Stumm D, Wester P, Zhang Y, Zhao L (2017) Review article: Inferring permafrost and permafrost thaw in the mountains of the Hindu Kush Himalaya region. Cryosphere 11 (1): 81-99. https://doi.org/10.5194/tc-11-81-2017

Jacquemart M, Loso M, Leopold M, Welty E, Berthier E, Hansen JSS, Sykes J, Tiampo K (2020) What drives large-scale glacier detachments? Insights from Flat Creek glacier, St. Elias Mountains, Alaska. Geology 48 (7): 703-707. https://doi.org/-10.1130/G47211.1

Kääb A, Leinss S, Gilbert A, Bühler Y, Gascoin S, Evans SG, Bartelt P, Berthier E, Brun F, Chao WA, Farinotti D, Gimbert F, Guo W, Huggel C, Kargel JS, Leonard GJ, Tian L, Désirée TD, Yao T (2018) Massive collapse of two glaciers in western Tibet in 2016 after surge-like instability. Nature Geoscience 11 (2): 114120. https://doi.org/10.1038/s41561-017-0039-7

Khadka D, Babel MS, Shrestha S, Tripathi NK (2014). Climate change impact on glacier and snow melt and runoff in Tamakoshi Basin in the Hindu Kush Himalayan (HKH) region. Journal of Hydrology (511), 49-60. https://doi.org/10.1016/j.jhy- drol.2014.01.005

Kirschbaum D, Watson CS, Rounce DR, Shugar D, Kargel JS, Haritashya UK, Amatya, P, Shean D, Anderson ER, Jo M (2019) The State of Remote Sensing Capabilities of Cascading Hazards over High Mountain Asia. Frontiers in Earth Science 7 (197): 1-25. https://doi.org/10.3389/feart.2019.00197 
Kulkarni A, Rathore BP, Singh SK, Bahuguna IM (2011) Understanding changes in the Himalayan cryosphere using remote sensing techniques. International Journal of Remote Sensing 32 (3): 601 615. https://doi.org/10.1080/01431161.2010.517802

Martha TR, Roy P, Jain N, Kumar KV, Reddy PS, Nalini J, Sharma SVSP, Shukla AK, Ra KHVD, Rao PVN, Muralikrishnan S (2021) Rock avalanche induced flash flood on 07 February 2021 in Uttarakhand, India-a photogeological reconstruction of the event. Landslides 18 (8): 1-13. https://doi.org/10.1007/s10346021-01691-9

Nakamura S, Omura Y, Angelopoulos V (2018) Recent wintertime climatic variability over the North West Himalayan cryosphere. Current Science: A Fortnightly Journal of Research 114 (4): 760770. https://doi.org/10.18520/cs/v114/i04/760-770

Nie Y, Zhang YL, Liu LS, Zhang JP (2010) Glacial change in the vicinity of Mt. Qomolangma (Everest), central high Himalayas since 1976. Journal of Geographical Sciences 20 (5): 667-686.

Pandey P, Chauhan P, Bhatt CM, Thakur PK, Kannaujia S, Dhote PR, Roy A, Kumar S, Chopra S, Bhardwaj A, Aggrawal SP (2021) Cause and Process Mechanism of Rockslide Triggered Flood Event in Rishiganga and Dhauliganga River Valleys, Chamoli, Uttarakhand, India Using Satellite Remote Sensing and in situ Observations. Journal of Indian Society of Remote Sensing 49: 1011-

1024. https://doi.org/10.1007/s12524-021-01360-3

Prasad AK, Yang K-HS, El-Askary HM, Kafatos M (2009). Melting of major Glaciers in the western Himalayas: evidence of climatic changes from long term MSU derived tropospheric temperature trend (1979-2008). Annales Geophysicae 27 (12): 4505-4519. https://doi.org/10.5194/angeo-27-4505-2009

Rafiq M, Mishra A (2016) Investigating changes in Himalayan glacier in warming environment: a case study of Kolahoi glacier. Environmental Earth Sciences 75 (23), 1-9. https://doi.org/10.1007/s12665-016$6282-1$

Salm B, Burkhard A, Gubler HU (1990) Berechnung von Fliesslawinen: Eine Anleitung fuer Praktiker; mit Beispielen. Mitteilungen des Eidgenoessischen Instituts fuer Schnee- und Lawinenforschung 47: 1-37.

Shang YJ, Yang ZF, Li LH, Liu DA (2003) A super-large landslide in Tibet in 2000: back-ground, occurrence, disaster, and origin. Geomorphology 54: 225-243. https://doi.org/10.1016/S0169-555X(02)00358-6

Shrestha AB, Wake CP, Mayewski PA, Dibb JE (1999) Maximum temperature trends in the Himalaya and its vicinity: an analysis based on temperature records from Nepal for the period 1971-94. Journal of Climate 12 (9): 2775-2786. https://doi.org/10.1175/1520-0442(1999)012<2775

Shugar DH, Jacquemart M, Shean D, Bhushan S, Upadhyay K, Sattar A, Schwanghart A, McBride S, Van Wyk de Vries M, Mergili M, Emmer A, Deschamps-Berger C, McDonnell M, Bhambri R, Allen S, Berthier E, Carrivick JL, Clague JJ, Dokukin M, Dunning SA, Fery H, Gascoin S, Haritashya UK, Huggel C, K b A, Kargel 
JS, Kavanaugh JL, Lacroix P, Petley D, Rupper S, Azam MF, Cook SJ, Dimri AP, Eriksson M, Farinotti D, Fiddes J, Gnyawali KR, Harrison S, Jha M, Koppes M, Kumar A, Leinss S, Majeed U, Mal S, Muhuri A, Noetzli J, Paul F, Rashid I, Sain K, Steiner J, Ugalde F, Watson CS, Westoby MJ, (2021) A massive rock and ice avalanche caused the 2021 disaster at Chamoli, Indian Himalaya.

Science. https://doi.org/10.1126/science.abh4455 (2021).

Singh DK, Mishra VD, Gusain HS (2020) Simulation and analysis of a snow avalanche accident in lower western Himalaya, India. Journal of the Indian Society of Remote Sensing 48 (11): 1555-

1565. https://doi.org/10.1007/s12524-020-01178-5

Singh P, Jain SK (2002) Snow and glacier melt in the Satluj River at Bhakra Dam in the western Himalayan region. Hydrological Sciences Journal 47 (1): 93-

106. https://doi.org/10.1080/02626660209492910

Singh P, Kumar N (1997) Impact assessment of climate change on the hydrological response of a snow and glacier melt runoff dominated Himalayan rive. Journal of Hydrology 193 (1-4): 316350. https://doi.org/10.1016/S0022-1694(96)03142-3

Tawde S, Kulkarni A, Bala G (2017) An estimate of glacier mass balance for the Chandra Basin, western Himalaya, for the period 1984-2012. Annals of Glaciology 58 (75): 1-

11. https://doi.org/10.1017/aog.2017.18

Tian SF, Chen NS, Wu H, Yang CY, Zhong Z, Rahman M (2020) New insights into the occurrence of the Baige landslide along the Jinsha River in Tibet. Landslides 17 (5): 1207-

1216. https://doi.org/10.1007/s10346-020-01351-4

Voellmy A (1995). Über die Zerstörungskraft von Lawinen. Schweizerische Bauzeitung, Sonderdruck aus dem 73. Jahrgang, 1-25.

Winiger M, Gumpert M, Yamout H (2005) Karakorum-Hindukush-western Himalaya: assessing highaltitude water resources. Hydrological Processes 19 (12): 2329-2338. https://doi.org/10.1002/hyp.5887

Wu CH, Hu KH, Liu WM, Wang H, Hu XD, Zhang XP (2020) Morpho-sedimentary and stratigraphic characteristics of the 2000 Yigong River landslide dam outburst flood deposits, eastern Tibetan Plateau. Geomorphology 367, 107293. https://doi.org/10.1016/j.geomorph.2020.107293

Xu Q, Zhang S, Li WL (2011) Spatial distribution of large-scale landslides induced by the 5.12 Wenchuan earthquake. Journal of Mountain Science 8 (2): 246-260. https://doi.org/10.1007/s11629-011-2105-8

Yao T, Pu J, Lu A, Wang YQ, Yu WS (2007) Recent Glacial Retreat and Its Impact on Hydrological Processes on the Tibetan Plateau, China, and Surrounding Regions. Arctic Antarctic \& Alpine Research 39 (4): 642-650. https://doi.org/10.1657/1523-0430(07-510)[YAO]2.0.CO 
Yin YP (2011) Recent catastrophic landslides and mitigation in China. Journal of Rock Mechanics and Geotechnical Engineering 3 (1): 10-18. https://doi.org/10.3724/ SP.J.1235.2011. 00010

Yin YP, Cheng YL, Liang JT, Wang WP (2016). Heavy-rainfall-induced catastrophic rockslide-debris flow at Sanxicun, Dujiangyan, after the Wenchuan Ms8.0 earthquake. Landslides 13 (1): 9-

23. https://doi.org/10.1007/s10346-015-0554-9

Yin YP, Li B, Zhang TT, Wang M, Wan JW, Liu XJ, Gao Y, Zhu SN (2021). The February 7 of 2021 GlacierRock Avalanche and the Outburst Flooding Disaster Chain in Chamoli, India. The Chinese Journal of Geological Hazard and Control 32 (3):1-8 (In Chinese).

Yin YP, Xing AG (2012) Aerodynamic modeling of the Yigong gigantic rock slide-debris avalanche, Tibet, China. Bulletin of Engineering Geology and the Environment 71 (1): 149-

160. https://doi.org/10.1007/s10064-011-0348-9

Zhang SL, Yin YP, Hu XW, Wang WP, Zhu SN, Zhang N, Cao SH (2020) Initiation mechanism of the Baige landslide on the upper reaches of the Jinsha River, China. Landslides 17: 2865-

2877. https://doi.org/10.1007/s10346-020-01495-3

Zhong Q, Chen S, Wang L, Shan Y (2020) Back analysis of breaching process of Baige landslide dam. Landslides 17 (7): 1681-1692. https://doi.org/10.1007/s10346-020-01398-3

\section{Figures}

\section{Figure 1}

Map of the study area terrain. In the remote sensing image, I and II represent the avalanche source on October 17 and 29, 2018, respectively, delineated by the red dotted lines.

\section{Figure 2}

Geological map of the Sedongpu Basin rock and glacier avalanche and adjacent 


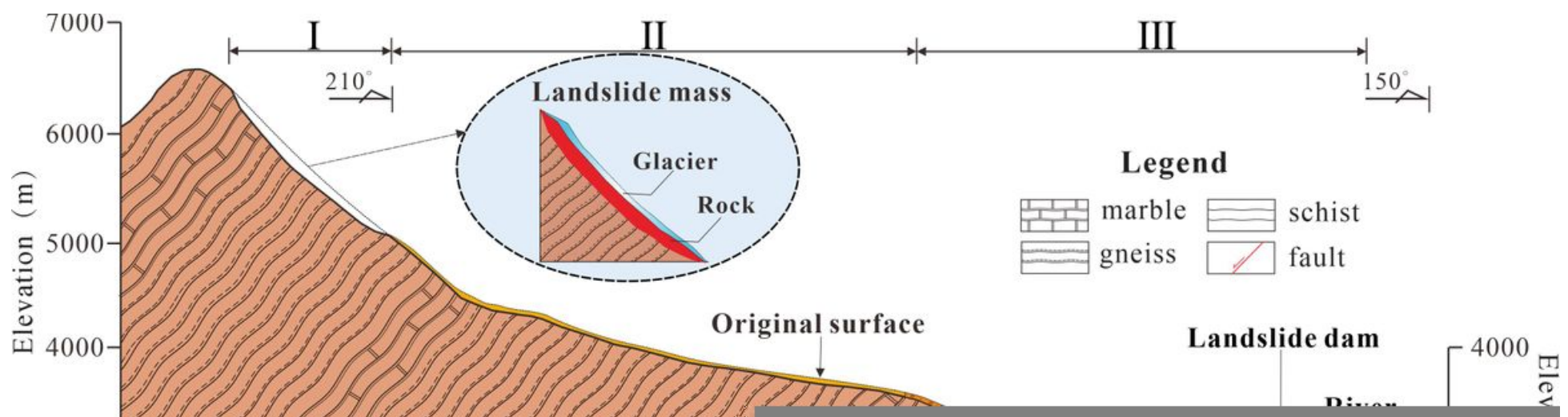

\section{Figure 3}

Movement of the rock and glacier avalanches disaster chain in the profile. I, source zone; II, dynamic erosion zone; III, debris flow accumulation and damming zone.

\section{Figure 4}

Multitemporal high-resolution remote sensing images of the source zone of the October 17, 2018, disaster. The purple dotted lines represent the source zone. The red arrows represent the movement direction.

\section{Figure 5}

Multitemporal high-resolution remote sensing images of October 29, 2018, source zone. The red dotted lines represent the source zone, the red arrows show the movement direction of the sliding body.

\section{Figure 6}

Satellite image of the dynamic erosion zone. Inset a is an overview photograph of the erosion zone. Inset b shows the gigantic sediment deposits. Inset c shows the sediment deposits on both sides of the valley. 
Satellite remote sensing image of the debris flow accumulation and damming zone. Zones I and II represent the accumulation zones of the disaster that occurred on October 17 and 29, 2018. The green lines stand for the geophysical profile locations. Insect $\mathbf{a}$ is an aerial photograph showing the landslide dam and breach. Insect $\mathbf{b}$ shows the sediment deposits piling up along the downstream valley.

\section{Figure 8}

Profile of the geophysical results. The purple dotted lines represent the boundary between bedrock and sediment deposits.

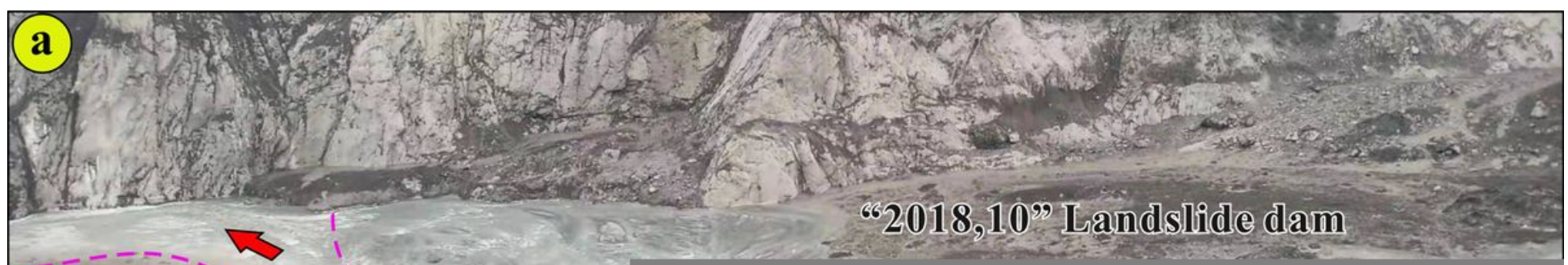

\section{Figure 9}


Landslide dam and dammed lake photographs from 2021. In a, the red arrows represent the water movement direction in the river, the red dotted lines represent the "2021, 3" landslide dam, the purple dotted lines represent the "2018, 10" landslide dam. b and c are aerial photographs of a disaster event occurring on August 17, 2021. B shows the deposits located in the Yarlung Zangbo River. In c, the red box shows the damaged bridge, and the blue arrows represent the submerged low terrain.

\section{Figure 10}

Map of the flood area in the disaster event of October 17, 2018. Inset a shows the flood flowing at the breach of the dam. Inset $b$ shows that the bridge was damaged by backwater. In inset $c$, the road was submerged by flood.

\section{Figure 11}

Schematic diagram of the RAMMS numerical simulation process for the Sedongpu Basin disaster chain

\section{Figure 12}

Images of the simulated runout velocities of the mixed rock and glacier mass at various times.

\section{Figure 13}

Simulating images of the accumulating depth at various times

\section{Figure 14}

Seismic distribution map of the study area and adjacent regions (data source: data.earthquake.cn).

\section{Figure 15}

Daily temperature variation in October 2018. 
Figure 16

Monthly mean rainfall and temperature variation of Milin County in 2018.

\section{Figure 17}

Mean rainfall in September 1999 to 2018 in Milin County. The red dotted line shows the multiyear mean rainfall.

\section{Figure 18}

Scenarios of the exit and run-out of rock and glacier avalanches. In a, the landslide mass deteriorated after the temperature rose, showing the widening process of crack. In b, the initial rock and glacier mass disintegrated after detaching. In $c$, the debris flow traveled and scoured on the path. In $d$, the dam formed and blocked the Yarlung Zangbo River.

\section{Figure 19}

Annual mean temperature (lines) and precipitation (bars) from 1980 to 2019 in Milin County. The red dotted line represents the temperature fitting curve (data source: China Meteorological Administration). 